\title{
Goodwill's Accounting Practices in Belgium and Compliance with IAS 36 Required Disclosures
}

\author{
Julius Gaël Tchatchou Tchaptchet ${ }^{1} \&$ Olivier Colot $^{1}$ \\ ${ }^{1}$ Warocqué School of Economics and Management, University of Mons, Mons, Belgium \\ Correspondence: Olivier Colot, Warocqué School of Economics and Management, University of Mons, Place \\ Warocqué, 17, 7000, Mons, Belgium.
}

Received: January 25, 2019

Accepted: February 14, 2019

Online Published: February 20, 2019

doi:10.5539/ibr.v12n3p139

URL: https://doi.org/10.5539/ibr.v12n3p139

\begin{abstract}
This paper aims at studying the impact of the accounting treatment of goodwill on the mandatory disclosure required by the International Accounting Standard (IAS) 36 on the impairment test of goodwill. We use a sample comprising 79 companies listed on Brussels stock exchange to show that there is a great heterogeneity in current accounting treatment of goodwill. We identify two groups of companies: those that display the goodwill on a separate line in their balance sheet and those that integrate it in their intangible assets. For the later, the only way to notice the presence of goodwill is by looking at the financial statement's notes presumably because those notes are expected to receive less scrutiny. Even if the compliance is not complete, the first group complies more with the paragraph 134 of IAS 36 than the other. Moreover, companies with a significant goodwill compared to both total assets and intangible assets are more compliant with IAS 36 . The findings finally reveal that the notices issued by the Financial Service and Markets Authority (FSMA) have a limited impact on the disclosure level. There are some areas of improvement but others such as goodwill allocation to cash generating unit, determination of the recoverable amount, description of key hypothesis and the sensitivity test need more effort on compliance.
\end{abstract}

Keywords: goodwill, IAS 36, impairment, disclosure, compliance

\section{Introduction}

Since January $1^{\text {st }}$, 2005, all listed companies in the European Union must have been preparing their consolidated financial statements in accordance with the International Accounting Standards (IAS) which are now International Financial Reporting Standards (IFRS). Those standards are more focused on shareholders who do not have insights into the company and therefore require from those companies to disclose more information than usual. The compliance with the disclosure requirements of IFRS reduces information asymmetry and enhances the ability of financial analysts to provide more accurate forecasts (Hodgdon, Tondkar, Harless \& Adhikari, 2008). Several studies have demonstrated that companies fail to comply with the disclosure requirements of IFRS (Gao \& Sidhu, 2018; Onali, Ginesti \& Ballestra, 2017). Based on a sample of 49 major firms from 12 countries around the world that claims to comply with IAS norms in 1996, Street, Gray and Bryant (1999) reveal a significant noncompliance with IASs. Areas of noncompliance include the use by some companies of inventory valuations not endorsed by the standard, failure to provide all required disclosures for property, plant and equipment... Moreover, some companies have exceeded the 20-year limit of goodwill amortization. Among all the areas required to be disclosed by IFRS, the accounting treatment of goodwill represents one of the most critical.

Goodwill is one of the most controversial assets in a company. This controversy comes from its definition, but also its estimation and accounting treatment (Bloom, 2009). During a business acquisition, the acquirer usually pays more than the accounting value of the acquired firm. The overpaid amount represents the goodwill and is sometimes vertiginous. Goodwill can be viewed as a component of the acquirer's investment or as the sum of the components that make it up (Johnson \& Petrone, 1998). It is based on the acquirer's expectations about future earnings from the acquired firm and the business combination. According to IFRS 3 (IASB 2004b), the entity shall recognize separately from goodwill, the intangible assets acquired. The adoption of this standard has led to a duality of practice regarding the accounting of the goodwill. Fabre and Farjaudron (2005) highlighted that many CAC 40's companies record their goodwill on a separate line in the balance sheet while some still included 
it in the intangible assets. This disaggregation is an accounting choice which allows financial statements users to have an overview of goodwill at the first glance on the balance sheet.

Besides its definition, the debate about goodwill recognition as an asset is also very intense and its impairment test procedures is criticized for the high complexity and subjectivity of the evaluation process required by IAS 36 (IASB, 2004a). The impairment test consists of comparing the carrying amount of an asset with its recoverable amount. With reference to IAS 36, an entity has to recognize an impairment loss if the carrying amount of an asset exceeds the amount to be recovered through the use or sale of the asset. Following this impairment, some information must be disclosed in order to help financial report's users better understand the parameters behind this process.

Devalle and Rizzato (2012) and many authors (Petersen \& Plenborg, 2010; d'Arcy \& Tarca, 2018; André, Filip \& Paugam, 2016) have contributed to the study on the compliance with the disclosure requirements of impairment of goodwill. Those studies conducted in France, Germany, Italy, Spain, and Australia in common have revealed a low degree of compliance regarding the requirements of IAS 36. This failure to comply has also been pointed out by the European Securities and Markets Authority (ESMA, 2013). This therefore led to recommendations to companies to better specify key assumptions used in the impairment test, including sensitivity analysis with enough details and transparency, to disclose specific discount rates for each material cash-generating unit rather than average discount rates. The Financial Services Markets Authority (FSMA) in Belgium has also observed this lack of compliance in the 2010's financial statements of companies listed in Brussels. Those companies were given notices to better comply with the requirements of IAS 36. It is important to analyze the context in Belgium compare to other countries and to see if the warnings of the FSMA which has the legitimacy and the authority to enforce international standards in Belgium, improved the disclosure.

Beyond compliance, previous contributions (among others Devalle \& Rizzato, 2012; Izzo, Luciani \& Sartori, 2013) have tried to find a link between the level of compliance with IAS 36 and other variables such as market capitalization, goodwill on equity ratio, goodwill on total assets ratio. But, none of them have considered the relation between the level of compliance with IAS 36 and the accounting practices of goodwill. This paper expands that window by focusing on goodwill impairment disclosure including its link with the accounting practices.

Starting from these uncertainties and concerns, the focus on goodwill will be addressed through the following research questions:

(a) What are the accounting practices of goodwill by Belgium listed companies?

(b) Are Belgium listed companies compliant with requirements of IAS 36 paragraph 134 ?

(c) Is the disclosure level of goodwill impacted by its accounting treatment?

(d) Has the disclosure improved after the notices issued by the Belgium public authorities (FMSA)?

The first two questions aim at examining the Belgium context compared to other countries. The two last questions introduce a new set of analysis as they bring together the way goodwill is recorded and its disclosure level. Moreover, we measure the impact of warnings issued by the FSMA on disclosure level.

Better than the level of impairment loss, a full compliance with IAS 36 is very important, not just to understand the inherent risk from the goodwill but also to help investors in the whole process of investment decision (Schatt, Doukakis, Bessieux-Ollier \& Walliser, 2016). The investors penalize much more the opacity of disclosure than the impairment loss (Izzo et al., 2013). The need of information is essential in the decision-making process. Moreover, the disclosure is an important determinant of forecast accuracy (Hodgdon et al., 2008). This paper aims at contributing to the accounting literature by providing results obtained in the Belgium context compare to studies conducted in other countries, and to evaluate if the fear of impairment is stronger or not than the risk of being too opaque to investors in Belgium.

Furthermore, this study will also benefit to control authorities and standard setters which need to find how to better enforce or improve international standards. In the discussion paper issued in July 2014 by the Accounting Standard Board of Japan (ASBJ), the European Financial Reporting Advisory Group (EFRAG) and the Italian Standard Setter (OIC), alternative approaches to the impairment test are explored such as a reintroduction of the amortization.

This analysis could also be of interest to auditors, financial advisors and researchers in order to improve the quality of goodwill's disclosure and to discuss on policy's recommendation and potential rules' improvements. 
This paper is organized as follow: section 2 provides the conceptual underpinnings and discusses prior findings. Section 3 describes our methodology and data set with section 4 presenting the main empirical findings and analysis. Section 5 concludes.

\section{Literature Review}

The primary sources of guidance on the recognition, measurement and impairment of goodwill are IAS 38 'intangible assets' and IAS 36 'impairment of assets'. Before addressing previous contributions in the field of accounting practices and the disclosure level of goodwill, it is essential to present the legal settings surrounding the disclosure of the goodwill's impairment test.

\subsection{Disclosure of Goodwill: Regulatory Frame Work and IAS 36}

A decade after the IASB adopted the "impairment only approach" in substitution of the "amortisation and impairment approach», the discussion around accounting and disclosure regarding the goodwill acquired in a business combination has become increasingly lively. The cost and the subjectivity of the impairment testing in accordance with IAS 36 are questioned. Furthermore, the usefulness of the information disclosed is challenged.

The debate about the impairment test of goodwill under IAS 36 are more energetic as its differs with the developments in the U.S. Private companies in the U.S. have the option to amortize goodwill arising from each business combination or reorganisation event that results in a fresh-start reporting (amortizable unit of goodwill), on a straight line basis over 10 years or less if it is appropriated and justified. This accounting standards update $\mathrm{N}^{\circ}$ 2014-02, intangibles - Goodwill and other (topic 350), issued in January 2014 by the FASB (Financial Accounting Standards Board in U.S.A.) is totally opposed to IAS 36 which does not permit anymore amortization of goodwill.

However, the amortization principle is not completely banned from IAS's norms as IFRS for SMEs requires to measure the goodwill acquired in a business combination at cost less accumulated amortization and accumulated impairment losses and if the entity is unable to estimate useful life, it can use 10 years (IFRS for SMEs, section 19 - Business combinations and goodwill). As for now, the IASB is planning on the reintroduction of goodwill amortization (The research group composed of the Accounting Standard Board of Japan, European Financial Reporting Advisory Group and the Italian Standard Setter's members, think that it would be appropriate and is more verifiable and reliable).

Under IFRS 3 and IAS 36, goodwill acquired in a business combination shall be accounted for using the acquisition method and tested for impairment. The acquisition method means that identifiable assets acquired, and the liabilities assumed shall be measured at their acquisition date fair values (Baboukardos \& Rimmel, 2014). As for the impairment test, the goodwill shall be allocated to cash generating units that are expected to benefit from the synergies of the combination. The test should then be ran at least annually at the cash generating unit level by comparing its carrying amount (including the goodwill), with its recoverable amount. An impairment loss is recognized if the first value is lower than the second one.

After his recognition into the accounts, the goodwill must be impaired in case of impairment loss. IAS 36 defines an impairment loss as the amount by which the carrying amount of an asset or a cash-generating unit (CGU) exceeds its recoverable amount. The latter being the higher of the fair value less costs to sell and the value in use. In his paragraph 10, IAS 36 adds that the goodwill impairment test shall be ran annually irrespective of whether there is any indication of impairment. Indicators of impairment may arise from an external and internal source.

Paragraphs 80 to 99 are devoted to the determination of the impairment procedure of goodwill. As the goodwill does not generate cash flows independently of other assets or groups of assets, it must be allocated to cash generating units that is expected to benefit from the synergies of the combination. A cash generating unit is defined by the standard as the smallest identifiable group of assets that generates cash inflows that are largely independent of the cash inflows from other assets or groups of assets. Therefore, the testing is carried out at the cash generating unit by comparing its carrying amount to its recoverable amount.

The key hypothesis used to determine the recoverable amount must be disclosed as required by paragraph 134 . This paragraph is very important as it describes in detail the information that have to be disclosed regarding the impairment test of goodwill. If the recoverable amount is determined through the value in use, the company must disclose the management's approach to determining the value(s) assigned to each key assumption. Moreover, the entity must disclose the period over which the cash flows have been projected based on financial budgets or forecast approved by management and the growth rate used to extrapolate cash flow projections beyond this period. It is essential to justify any period greater than five years or growth rate that exceeds the long-term 
average growth rate specific to company's characteristics (products, industries, market...). Finally, the discount rate(s) applied to the cash flow projection must be disclosed.

The recoverable amount can also be determined through the fair value less costs to sell. The latest is obtained through an observable market price for the CGU or a discounted cash flow projection. In the first case, the company must describe each key assumption and the approach to determining the value assigned to each to them. In the second case, the company must disclose the period over which management has projected cash flows, the growth rate used to extrapolate cash flow projections and the discount rate applied to the cash flow projections.

Finally, the company must run a sensitivity test which consists of varying the key assumptions on which the management has based its determination of the cash generating unit's recoverable amount. After those operations, if the carrying amount appears to be more than the recoverable amount, the company must disclose the surplus amount and the value assigned to the key assumption.

Many authors have examined the nature of goodwill and the compliance with IAS 36 (Glaum, Schmidt, Street \& Vogel, 2013).

\subsection{Summary of Previous Research}

The research stream about goodwill and his disclosure level under IAS 36 is extensive. According to Marston and Shrives (1991), "calculating an index score for a particular company can give a measure of the extent of disclosure but not necessarily the quality of the disclosure. Items included in the disclosure index may be weighted in order to take account of the fact that some items are viewed as more important than others".

The term goodwill is used in diverse domains such as marketing, sociology, human sciences or economy. Labelled by Gélard (2013) as an unidentified accounting object, goodwill is a catch-all term, that is, a category in which we place unclassified items. It underlines the fact that it is a concept full of ambiguity, subject of many accounting theories. In their essay on 'the theoretical foundation of goodwill', Ratiu and Tudor (2013) give this definition of accounting theory by Devine (1985): "entire complex of logical rules, primitive terms and semantic rules of correspondence, interpretations, definition, and theorems, necessary to explain behavioral and physical observations".

The debate around goodwill firstly began with his definition. Leake (1921) defines goodwill as a super-profit, that is, "the amount by which revenue, increase of value, or other advantage received exceeds any and all economic expenditure incidental to its production".

Afterwards, the debate turned into the recognition of goodwill as an intangible asset. In accordance with IAS 38 and IFRS 3 (as revised in 2008), an acquirer must recognize at the acquisition date, separately from goodwill, the intangible assets of the acquired firm. This is a strong argument for those who think that goodwill is not an intangible asset and record it on a separate line in the balance sheet. However, some companies consider the goodwill as an intangible asset and incorporate it in the later. Another explanation of incorporating goodwill into intangible assets is the will of hiding it. Disaggregated numbers come under close scrutiny and disaggregated line items represent materiality benchmarks (Libby, Rennekamp \& Seybert, 2015). By studying the effects of earnings presentation regulations on auditor behavior, Libby and Brown (2013) find that disaggregation on the face of the financial statements reduces the average amount of misstatement that auditors report they will tolerate.

In their study on CAC 40's companies of the French stock markets, Fabre and Farjaudon (2005) found that almost $80 \%$ of their sample records the goodwill on a separate line in the balance sheet while the other incorporates it in their intangible assets. Given the proximity of the French stock market and the Belgium stock market, we expect to find the same trend amongst Belgium listed companies. In this case, the hypothesis tested is:

$\mathrm{H}_{1}$. Companies listed on Brussels stock exchange register their goodwill on a separate line in the balance sheet.

After his recognition into the accounts, the debate around goodwill came to his accounting treatment in subsequent years. Leake (1921) and Nelson (1953) share the idea of writing off the goodwill in the period that the super-profits are expected to be earned. This position was first adopted by the IASB in IAS 22 before his replacement by the present impairment test.

The goodwill is now depreciated annually in accordance with IAS 36 which requires also the disclosure of some information related to this depreciation in order to help stakeholder in their decisions. Numerous authors have conducted studies about this disclosure which is supposed to reduce information asymmetries and improved forecast accuracy. 
Referring to the year 2010, Devalle and Rizzato (2012) show that the disclosure index of groups listed on Italian, French, German and Spanish Stock Exchanges is very low with wide differences between markets analyzed. Only $27 \%$ of their sample of 141 companies reports the mandatory disclosure of goodwill. The information that was less disclosed was the analysis of sensitivity. Carlin, Finch and Ford (2007) analyze the quality of disclosure on goodwill impairment during 2006 for the top 20 companies by market capitalization on the Australian Stock Exchange. They found that the rates of clear noncompliance were surprisingly high. Only $25 \%$ provided disclosures which contained enough detail as required by the standard. Moreover, for most companies, it is not possible to replicate the sensitivity analysis which means that financial statement users have a passive role instead of active like critical analysts. Some required disclosures were regularly omitted. This may perhaps be attributed to the fact that we were at the beginning of implementation of the new standards. But subsequent studies reveal that the situation is not improving.

Izzo et al. (2013) carried a most recent study on Italian listed companies. They examined whether financial crisis has impacted the level of compliance with IAS 36 and guidelines issued by Italian Authorities. They analyzed financial statements from 2007 to 2011 of Italian companies that are listed on FTSE MIB of Milan Stock Exchange at $31^{\text {st }}$ December 2012. Their results showed that the disclosure level is still very incomplete, but at the same time many companies have registered a substantial increase in the quality of their disclosure in one of these 5 years. They also found that there is not a relation between the quality of mandatory disclosure on goodwill and the impairment rate, goodwill/equity or market capitalization.

In a most recent study conducted by Andre, Dionysiou and Tsalavoutas (2018) on companies of the S\&P Europe 350 index, evidence of noncompliance regarding IAS 36 are revealed. Most of the firms do not describe the assumptions used nor the approach used for determining these assumptions. Moreover, the period and the rate used to extrapolate cash flows beyond the period covered by management budgets are not justified. The authors add that these critical information for investors are not disclosed on a voluntary basis because it can cause significant damages to the company.

Finally, D'Arcy et Arca (2018) analyze and summarize the current research about goodwill recognition, impairment and disclosure. Overall, they documented substantial evidence of noncompliance related to the disclosure both for cross-country studies (Glaum, Schmidt, Street \& Vogel, 2013; Hartwig, 2015; Mazzi, André, Dionysiou \& Tsalavoutas, 2017) and single country studies (Bepari, Rahman \& Mollik, 2014; Devalle, Rizzato $\&$ Busso, 2016).Given those previous contributions, our second hypothesis tested is:

$\mathrm{H}_{2}$. There is a lack of compliance with the requirements of IAS 36 on Belgium markets.

Beyond the compliance to IAS 36, researchers have tried to explain the disclosure level observed with some variables such as earnings, costs of capital ...In investigating the impact of compliance with the disclosure requirements of IFRS on analyst's earnings forecast errors, Hodgdon et al. (2008) find a negative correlation between these two variables. Companies providing all or most of the financial disclosures required by IFRS, enable financial analysts to better predict earnings per share. In a recent study, Mazzi, André, Dionysiou and Tsalavoutas (2017) find a significant negative relation between implied cost of equity capital and compliance with mandated goodwill related disclosure. Using a sample of European firms of the S\&P 350 over the period 2008 to 2011, they argue that investors seek additional information through these disclosures in order to mitigate information risk.

In this study, we introduce a new set of variables that had not been investigated before: the place of goodwill in the balance sheet and its proportion in intangible assets and total assets. Our starting idea is that companies recording goodwill on a separate line emphasize its importance as a real asset in the sense that it provides future economic benefits to the combined firm (Lys, Vincent \& Yehuda, 2012), and should give even more clear information and accurate disclosure that the one incorporating it in their intangible assets. In this case, our third hypothesis is:

$\mathrm{H}_{3}$. Companies registering the goodwill on a separate line in the balance sheet comply more with IAS 36 than those incorporating it in intangible assets. Moreover, companies with a material goodwill compared to both intangible assets and total assets comply more with IAS 36 than others.

Authorities have raised concerns about this non-compliance and urged companies to do more in satisfying international standards. In a report issued in 2011 and analyzing a sample of 235 European companies from 23 countries, the European Securities and Markets Authority (ESMA, 2013) found that the disclosure was too general and not detailed enough. Furthermore, in analyzing the 2010 financial statements of Belgium listed companies, the FSMA revealed that the information disclosed did not comply entirely with the standard. Area of non-compliance includes the definition of CGU, allocation of goodwill to CGU, determination of the recoverable 
amount, growth and discount rates, and the sensitivity analysis. Three years later, it appears essential to see if the situation improved. Given the legitimacy and the supervising role of the FSMA, we expect to see an improvement of the disclosure level. The fourth hypothesis is then:

$\mathrm{H}_{4}$. The disclosure level improved in 2013 compared to 2010 after the warnings issued by FSMA.

To accomplish the study's objectives and test the hypothesis, a methodology is elaborated in order to collect and analyze the data.

\section{Data and Methodology}

This research is structured by 6 phases: (1) the data collection and construction of the final sample to be used, (2) the identification of companies whose disclosure level of goodwill under IAS 36 will be assessed, (3) the construction of the assessment grid on goodwill disclosure, (4) the calculation of a disclosure index for each company, (5) the assessment of firms according to that index, and finally (6) the comparison with FSMA findings and recommendations.

To address the objectives mentioned, we analyze financial statements published by Belgium's listed companies. Those reports have been downloaded from the Belgium's National Bank website where companies have to drop off annually their financial statements. The Bel-first database is also use in order to extract for each company, financials data such as goodwill, intangible assets, current and non-current assets and total assets. The analysis is performed firstly by ranking companies with a goodwill (sample 1) according to its weight in total assets and intangible assets. The place of goodwill in the balance sheet is examined. Secondly, each company with a significant goodwill (sample 2) is judged on whether or not it disclosed every information required by IAS 36 . To perform this assessment, we elaborate a disclosure grid (Appendix 1). Finally, we examine the disclosure level according to the classification we built and the place of goodwill in the balance sheet.

\subsection{Data Collection and Description of the Samples}

Table 1 shows the sample of companies listed on Brussels stock exchange on March 1, 2015.

Table 1. Sample selection

\begin{tabular}{lrr}
\hline Item & Calculation & $100.00 \%$ \\
\hline Companies listed on Euronext Brussels & 181 & $58.56 \%$ \\
Companies without goodwill & 106 & $41.44 \%$ \\
\hline Intermediate sample 1 & 75 & \\
\hline & & \\
Companies who depreciated totally their goodwill during the & 4 & $\mathbf{4 3 . 6 5 \%}$ \\
\hline Fear 2012 & & $\mathbf{7 9}$ \\
\hline
\end{tabular}

This table shows the total number of companies that remain after applying cumulatively each treatment to the original data. From the 181 companies listed on this market, we are interested only to the 75 that present a goodwill at the end of the year 2013. In order not to dismiss companies which have depreciated entirely their goodwill during the year 2013, we added them to our sample and obtain a final sample of 79 companies. Those companies are almost all (99\%) quoted on Euronext which is the regulated part of Brussels stock exchange. Moreover, 39\% of companies of the sample have a market capitalization which is more than a billion of euros, followed by those with a market capitalization between EUR 1 billion and EUR 150 million (33\%). Regarding the activity area, industrials and financials are the most represented (22\% each), followed by consumer goods $(15 \%)$ and consumer services $(10 \%)$.

Companies that the disclosure level of goodwill under IAS 36 is assessed are extracted from this first sample.

\subsection{Companies to be Assessed Regarding Their Disclosure Level of Goodwill Impairment Test}

According to IAS 36, companies that must disclose information required by his paragraph 134 are those that the goodwill is significant in comparison with the company's total carrying amount of goodwill. However, there is no indication about the significance of the goodwill, but we can refer to IAS 8 paragraph 5 which specifies that an element is significant if it can affect economic decisions made by financial statement's users. We used the same level of significance as FSMA. In other words, we considered that the amount of goodwill is significant if it is superior or equal to 5\% of total assets. These new criteria allowed us to define a more reduced sample. Our new sample contains 46 companies that have a goodwill superior or equal to $5 \%$ of total assets. We added to those companies, one other firm that have a significant goodwill during the year 2013 but due to a depreciation, the goodwill amount felt under $5 \%$ of total assets. Our final sample is then 47 companies distributed like shown in table 2. 
Table 2. Repartition of companies with a significant goodwill

\begin{tabular}{lcll}
\hline Area of activity & Number & $\begin{array}{l}\text { Goodwill/total } \\
\mathbf{( 2 0 1 2 )}\end{array}$ & $\begin{array}{l}\text { assets } \\
\begin{array}{l}\text { Goodwill/total } \\
(\mathbf{2 0 1 3})\end{array}\end{array}$ \\
\hline Basic materials & 2 & $14.65 \%$ & $16.38 \%$ \\
Consumer goods & 8 & $36.55 \%$ & $49.11 \%$ \\
Consumer services & 7 & $28.73 \%$ & $30.20 \%$ \\
Financials & 4 & $05.57 \%$ & $12.68 \%$ \\
Healthcare & 4 & $50.32 \%$ & $46.37 \%$ \\
Industrials & 10 & $21.39 \%$ & $20.99 \%$ \\
Technology & 7 & $23.82 \%$ & $26.99 \%$ \\
Telecommunications & 2 & $25.23 \%$ & $24.32 \%$ \\
Utilities & 3 & $14.69 \%$ & $13,27 \%$ \\
\hline Total & $\mathbf{4 7}$ & $\mathbf{2 1 . 6 2 \%}$ & $\mathbf{2 5 . 2 9 \%}$ \\
\hline
\end{tabular}

This table shows the activity areas of companies that the goodwill is at least $5 \%$ of total assets. The most represented sectors are industrials and consumer goods with respectively 10 and 8 companies. The total goodwill of our sample represents $25 \%$ of the total assets in 2013, a $4 \%$ increase compared to 2012.

In order to assess the quality of disclosure provided on the impairment of goodwill, we have defined an index of disclosure based on the model defined by Botosan (1997).

\subsection{The Disclosure Index}

The assessment has been made on information provided by companies in their annual reports. Companies must prepare and present their financial statements in accordance with IAS 1 - presentation of financial statements. Those financial statements are included in the annual report which is wider in scope and includes future plans and strategies of the firm. Annual report is a good proxy for the level of voluntary disclosure provided by a firm across all others means of corporate reporting (Botosan, 1997).

One of the most important steps of our research has been the construction of the assessment grid based on the requirements contained in IAS 36, paragraph 34. The grid presented in appendix 1 is composed of two columns: the first one indicates the specific information that company has to disclose in the notes and the second one contains the pertaining score allocated to each company. The score is 1 if the information is disclosed and 0 if not. A third option (N/A: Not Applicable) is available for companies that are not concerned by the requirement.

\section{Results \& Analysis}

In this section, we present the results of our study.

\subsection{Descriptive Statistics}

Table 1. Summary

\begin{tabular}{lllll}
\hline Items & Mean & Std. Dev & Max & Min \\
\hline Goodwill/total assets & $13.95 \%$ & $15.37 \%$ & $52.62 \%$ & $0.050 \%$ \\
Intangible assets /total assets & $8.03 \%$ & $12.93 \%$ & $85.25 \%$ & $0.002 \%$ \\
Goodwill/(intangible assets + goodwill) & $65.47 \%$ & $29.77 \%$ & $10.00 \%$ & $3,600 \%$ \\
Goodwill/current assets & $27.08 \%$ & $24.87 \%$ & $87.13 \%$ & $0.070 \%$ \\
Goodwill + intangible assets)/total assets & $21.67 \%$ & $21.05 \%$ & $98.67 \%$ & $0.080 \%$ \\
\hline
\end{tabular}

Table 3 reports summary statistics for the main ratios used in the accounting practices of goodwill. This table shows the mean and the standard deviation of the main ratios used in the analysis of sample 1 determined in Table 1. The maximum and the minimum of each ratio are also presented.

Among the tested variables, we observe a significant gap between the highest and the smallest value. The proportion of goodwill on total assets is on average higher than the one of intangible assets (without goodwill) on total assets. Furthermore, compared to intangible assets and current assets, goodwill is material. The above evidence seems to confirm the significance of goodwill among all firms' assets. Goodwill represents on average $14 \%$ of total assets of the analyzed sample. This is consistent with the findings of Izzo et al. (2013) where the proportion of goodwill on total assets between 2007 and 2011 varied from 12\% to 14\% in the case of Italian firms analyzed.

\subsection{Accounting Practices of Goodwill}

Table 2. Place of the goodwill

\begin{tabular}{llr}
\hline Item & Sampling & $\%$ \\
\hline Goodwill incorporated in the intangible assets & 24 & 30.38 \\
Goodwill recorded on a separate line & 55 & 69.62 \\
Total & 79 & 100.00 \\
\hline
\end{tabular}


Table 4 presents how companies place the goodwill in the balance sheet. We observe a heterogeneity of accounting practice about goodwill. The place of goodwill in the balance sheet is different, sometimes it is incorporated in the intangible assets or it has its own line in the balance sheet.

The majority of companies of our sample distinguish the goodwill from others intangible assets by recording it on a separate line in the balance sheet, even if the amount is not significant compared to total assets. This marks a big slope in favor of those who think that the goodwill is an asset distinguishable from other assets. However, there still a non-negligible part who considers the goodwill as an intangible asset in their balance sheet. One might think that this stems from the desire to conceal the amount of goodwill. Fabre and Farjaudon (2005) believe that a costly transaction leads companies to hide the goodwill amount by incorporating it in their intangible assets. Our findings are consistent with theirs on CAC 40 companies as they found that the majority (80\%) of companies listed on CAC 40 register the goodwill on a separate line. We then follow their methodology in representing a cartography of the part of goodwill in total assets and intangible assets (goodwill included) respectively.

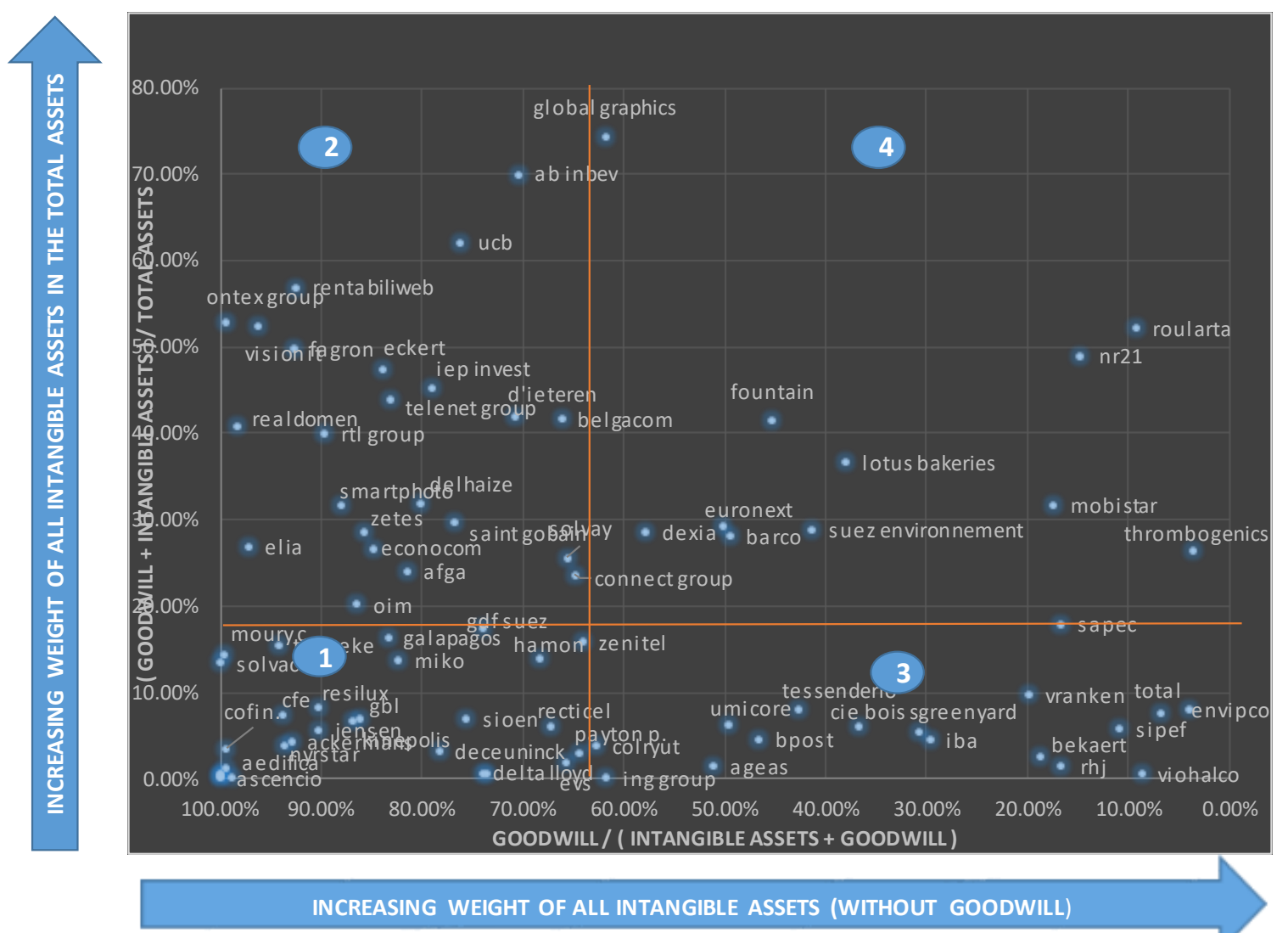

Figure 1. Mapping of goodwill's weight

Figure 1 gives an overview of the weight of the goodwill and intangible assets in each company of our sample.

In this figure, we measure the weight of goodwill compared to the total intangible assets including goodwill (horizontal axis) and the weight of the latest compared the total assets (vertical axis). The median of the two ratios are respectively $64.86 \%$ and $27.08 \%$, represented by both orange lines in the graph. These two values define 4 groups in our sample:

- Group 1: Goodwill represents the main part of intangible assets (more than 64\%) which in his turn represent less than $27 \%$ of the total assets;

- Group 2: Weak recognition of intangible assets but the goodwill remains important compared to total assets;

- Group 3: Big proportions of intangible assets (without goodwill) but with a limited impact on total assets;

- Group 4: Big proportions of intangible assets (without goodwill) which represent an important part of total assets. 
The high degree of recognition of intangible assets (goodwill excluded) by companies of group 4 suggests an alignment with the disposition of IFRS 3 as it leads to a greater appreciation of intangible assets (Fabre and Farjaudon, 2005) (According to paragraph B31 of IFRS 3, the acquirer shall recognize, separately from goodwill, the identifiable assets acquired in a business combination). However, companies of other groups may experience hard time in implementing those norms as they did not identify much more intangible assets separately from goodwill. It is interesting to see how those groups behave in terms of disclosure concerning the goodwill impairment test.

\subsection{Evaluation of the Disclosure Index of Goodwill under IAS 36}

The disclosure level of the 47 companies with a goodwill which represents at least $5 \%$ of total assets has been assessed. The results exhibit that $89 \%$ of those companies gave information about their CGU with a large part of them (60\%) matching the CGU to operational sectors. Most of the time, CGUs are just enumerated without information that give a clear view of the risks they face as recommended by the FSMA.Very often, operating segments coincide with a subsidiary or a market area which establishes its own financial statement. This appears to be a way out for companies that don't want to involve in the process of identifying the smallest group of assets which will benefit from the goodwill.

The majority (87\%) of companies provided a complete reconciliation of the total accounting value of the goodwill with the parts allocated to the CGUs. Without this information, it is not possible for financial statements' users to evaluate the risk associated to the CGUs. In order to determine the recoverable amount, there are 34 companies over 47 (72\%) to use the value in use method, 5 companies use the fair value less costs to sell method and 3 companies use both methods. The value in use is also the most used method in the study conducted by Devalle and Rizzato (2012) as it is applied by 98\% of companies listed on Paris, Frankfurt, Madrid and Milan stock exchanges.

For the 37 companies which used the value in use (34 plus the 3 which used the two methods), 27 have gave a description of the key assumption used in the determination of the cash flows. Those cash flows have been projected for most of them (34 companies) over a period of at least five years. All these companies have disclosed the rates applied to the cash flows as indicated in table 5.

Table 3. Growth and discount rates

\begin{tabular}{llclc}
\hline & & Growth rate & Discount rate \\
\hline Item & Number & \% sample analyzed & Number & \% sample analyzed \\
\hline Same rate for all CGU & 21 & 32.43 & 17 & 45.95 \\
Different rate/CGU & 12 & 56.76 & 15 & 40.54 \\
Rate interval & 4 & 10.81 & 5 & 13.51 \\
Total & $\mathbf{3 7}$ & $\mathbf{1 0 0 . 0 0}$ & $\mathbf{3 7}$ & $\mathbf{1 0 0 . 0 0}$ \\
\hline
\end{tabular}

This table shows the number of companies according to the way they disclose the growth and the discount rates.

For companies which disclosed only a rate band, it is not possible to know what the exact growth is used.

For companies using the fair value less costs to sell method, half of them determine this value through the discounted flow projections, while 3 companies used the observable market price method and one company both methods.

As for the sensitivity analysis, it has been run by 33 companies with $73 \%$ of them claiming that the recoverable amount will exceed the carry amount and therefore there is no depreciation to be expected. Multiple variations in the hypothesis have been used to test the sensitivity.

Those findings are consistent with our first hypothesis which state that the compliance in Belgium is not complete in the same way as his European peers.

\subsection{Findings According to the Accounting Practices of Goodwill}

Previous research didn't take into consideration the relation between the place of the goodwill in the balance sheet and the disclosure level of goodwill under IAS 36. This relationship is analyzed in table 6.

Table 4. Disclosure level according to the goodwill's place

\begin{tabular}{|c|c|c|c|c|c|}
\hline Item & Obs & Mean score & Standard deviation & $\mathrm{t}$ & $\operatorname{Pr}(\mathrm{T}>\mathrm{t})$ \\
\hline Goodwill recorded on a separate line & 35 & $67.14 \%$ & $20.52 \%$ & \multirow{2}{*}{2.28} & \multirow{2}{*}{$0.015^{*}$} \\
\hline Goodwill incorporated in the intangible assets & 12 & $53.33 \%$ & $17.23 \%$ & & \\
\hline
\end{tabular}

*Significant at the $1.5 \%$ 
This table shows the mean and the standard deviation of companies' disclosure score according to the place of goodwill in the balance sheet. The results obtained exhibit that there is a significant difference between the disclosure level of companies that recorded goodwill on a separate and those incorporating it in the intangible assets. This difference is in favor of the first group which represents $74 \%$ of our sample. Considering a standard deviation of $17 \%$, we can highlight that companies considering goodwill as an asset distinguishable from other intangible assets, tend to be more compliant with the paragraph 134 of IAS 36 than those incorporating their goodwill in the intangible assets. This confirms our hypothesis that the place of goodwill in the balance sheet has an impact on its impairment disclosure under IAS 36. It appears interesting to go deeper into the elements disclosed in order to confirm this trend. Table 7 presents the results.

Table 5. Comparison of the disclosure level according to goodwill's place

\begin{tabular}{|c|c|c|c|c|c|}
\hline $\mathbf{N}^{\circ}$ & Item & $\begin{array}{l}\text { Goodwill } \\
\text { incorporated in the } \\
\text { intangible assets }\end{array}$ & Goodwill recorded on a separate line & $\mathbf{Z}$ & $\operatorname{Pr}(|\mathbf{Z}|<|\mathbf{z}|)$ \\
\hline 1 & $\begin{array}{l}\text { Goodwill allocation } \\
\text { to CGU }\end{array}$ & $83.33 \%$ & $88.57 \%$ & 0.47 & 0.639 \\
\hline 2 & $\begin{array}{l}\text { Determination of the } \\
\text { recoverable amount }\end{array}$ & $91.67 \%$ & $88.57 \%$ & -0.30 & 0.764 \\
\hline 3 & $\begin{array}{l}\text { Description of each } \\
\text { key assumption }\end{array}$ & $41.67 \%$ & $62.86 \%$ & 1.28 & 0.200 \\
\hline 4 & $\begin{array}{l}\text { Projection period of } \\
\text { cash flows }\end{array}$ & $75.00 \%$ & $80.00 \%$ & 0.37 & 0.715 \\
\hline 5 & Growth rate & $75.00 \%$ & $80.00 \%$ & 0.37 & 0.715 \\
\hline 6 & Discount rate & $75.00 \%$ & $80.00 \%$ & 0.37 & 0.715 \\
\hline 7 & Sensitivity test & $58.33 \%$ & $74.29 \%$ & 1.04 & 0.297 \\
\hline
\end{tabular}

This table compares the disclosure level of each item to be disclosed according to the place of goodwill in the balance sheet. We find that the proportions are not statically different from each other. For the both categories of companies, it can be observed that there is no significant difference in terms of goodwill disclosure. This finding contrast with the previous one about the overall disclosure of the two groups and can be explained by the low ( $\leq$ $50 \%$ ) score obtained by eight companies of the first group (companies recording their goodwill on a separate line).

To complete this analysis with goodwill's account practices, the disclosure level of the four groups identified in fig 1 has been examined. For each group, the mean score is determined, along with the standard deviation as presented in table 8 .

Table 6. Disclosure level by group

\begin{tabular}{lcllclc}
\hline Item & Obs & Mean score & Standard & deviation & t & Pr(T < t $)^{*}$ \\
\hline Group 1 & 17 & $61.18 \%$ & $20.58 \%$ & -2.00 & 0.0272 \\
Group 2 & 17 & $72.94 \%$ & $12.63 \%$ & & \\
Group 3 & 2 & $55.00 \%$ & $70.71 \%$ & -3.06 & 0.0221 \\
Group 4 & 11 & $54.55 \%$ & $26.97 \%$ & -2.12 & 0.0267 \\
\hline
\end{tabular}

*Test between group 2 and other groups. The tests statistics between other groups are not significant and therefore are not presented here.

This table compares the disclosure level of group 2 identified in Figure 1 with the disclosure level of other groups. The results obtained show that group 2 has the higher level of disclosure and this is significant compared to the disclosure level of other groups. Considering this consideration, we can highlight:

- Companies with a high level of goodwill compared simultaneously to intangible assets and total assets tend to comply more with IAS 36 par 134 than the others.

- Those companies have a disclosure level higher or equal to $50 \%$ and for 8 over 17 of these companies, the disclosure level is at least $80 \%$.

- The majority of those companies (82\%) has recorded their goodwill on a separate line in the balance sheet which reinforces our previous finding that companies with a goodwill registered on a separate line in the balance sheet tend to be more compliant to IAS 36 than those incorporating it in the intangible assets.

As for other groups (1,3 and 5), there is no significant differences between their disclosure level. Following this analysis, table 9 below shows that big companies complies better to IAS 36 than small one. 
Table 7. Disclosure level by market capitalization

\begin{tabular}{llll}
\hline Item & Large Cap & Middle Cap & Small Cap \\
\hline Mean score & $70.00 \%$ & $68.89 \%$ & $57.22 \%$ \\
Standard deviation & $12.59 \%$ & $22.05 \%$ & $21.64 \%$ \\
\hline
\end{tabular}

This table compares the disclosure level of the different compartment of the market. Compliance seems to be a matter of size: size of the companies in terms of market capitalization and size of the goodwill compared to others intangible assets and total assets.

\subsection{Comparison with FSMA Findings and Recommendations}

We use a t-test to understand whether there was an improvement in disclosure level, one year after the report and the warning issued by the regulator regarding the disclosure level of the year 2010. In other words, we compare the disclosure level before and after the FMSA raise the alarm about area of non-compliance.

Table 8. Comparison of the disclosure level in 2010 and 2013

\begin{tabular}{|c|c|c|c|c|c|}
\hline $\mathbf{N}^{\circ}$ & Item & $\begin{array}{l}\text { Disclosure level in the } \\
2013 \text { financial } \\
\text { statement (our study) }\end{array}$ & $\begin{array}{l}\text { Disclosure level in the } \\
2010 \text { financial } \\
\text { statement (from the } \\
\text { FSMA report) }\end{array}$ & $\mathbf{Z}$ & $\operatorname{Pr}(|\mathrm{Z}|<|\mathrm{z}|)$ \\
\hline 1 & $\begin{array}{l}\text { Goodwill allocation to } \\
\text { CGU }\end{array}$ & $87.00 \%$ & $86.00 \%$ & 0.13 & 0.894 \\
\hline 2 & $\begin{array}{l}\text { Determination of the } \\
\text { recoverable amount }\end{array}$ & $89.36 \%$ & $94.59 \%$ & -0.86 & 0.389 \\
\hline 3 & $\begin{array}{l}\text { Description of each key } \\
\text { assumption }\end{array}$ & $72.97 \%$ & $61.29 \%$ & 1.03 & 0.305 \\
\hline 4 & $\begin{array}{l}\text { Projection period of } \\
\text { cash flows* }\end{array}$ & $100 \%$ & $87.10 \%$ & 2.25 & 0.024 \\
\hline 5 & Growth rate* & $100 \%$ & $87.10 \%$ & 2.25 & 0.024 \\
\hline 6 & Discount rate* & $100 \%$ & $83.87 \%$ & 2.54 & 0.011 \\
\hline 7 & Sensitivity test & $59.46 \%$ & $70.21 \%$ & -0.92 & 0.357 \\
\hline
\end{tabular}

*Significant at the $2.5 \%$ level.

This table compares the disclosure level in 2010 from the study of the FSMA and 2013 from our study. From the outputs, we see that the $\mathrm{p}$ value is significant for the projection period of cash flows, the growth rate and the discount rate which means that there is an improvement in the disclosure of those information. On the other hand, disclosure on goodwill allocation to CGU, determination of the recoverable amount, description of each key assumption and the sensitivity test didn't get better. With 3 items on 7 that the disclosure enhanced, the warnings and recommendations of FSMA produced a limited impact on the disclosure level.

\section{Conclusion}

In this paper, we offered a deep analysis of the accounting practices of goodwill and its disclosure level under IAS 36. The paper addresses the question of compliance with the paragraph 134 of IAS 36 and its relationship with the accounting treatment. We attempt to answer this question by analysing the financial statements and notes of the year 2013 of companies listed on Brussels stock exchanges. The results show a heterogeneity of accounting practices of goodwill. The majority of companies (55 out of 79) record the goodwill on a separate line in the balance sheet while other integrates the goodwill in their intangible assets. In this last case, the only way to attest the presence of goodwill is by looking in the notes of the financial statements. Libby and Brown (2013) find that disaggregation increase the reliability of reported financial statement numbers. This finding reinforces the position of IFRS which recommends registering the goodwill as an asset different from other intangible assets. The same trend has been identified by Fabre and Farjaudon in their study on the CAC 40 index of the French market.

Consistent with previous studies (among others Devalle and Rizzato, 2012; Izzo et al., 2013), our results on compliance with IAS 36 reveal that the Belgium market is not different from his peers in Europe. Every firm in the sample that has a goodwill which accounts for at least $5 \%$ of the total asset was assessed. It appeared that companies listed in Brussels do not fully comply with IAS 36 but there are some areas of improvement since the warnings issued by the Belgium control authority. These results are troubling since they suggest that the authority of the Belgium's supervisor is undermined. The influence of the FSMA on the disclosure level is limited. The period over which the cash flows have been projected, the growth rate and the discount rate are the only areas to have been better disclosed. 
Moreover, we analysed the disclosure level according to the goodwill's place in the balance sheet. Taking items to be disclosed individually, we find that there is no difference on disclosure level between the group of companies which register goodwill on a separate line in the balance sheet and those that do not. In contrast, the disclosure level of companies recording goodwill on a separate line is higher than the one for companies integrating it the intangible assets. Furthermore, the disclosure level is better for companies with a material amount of goodwill in regard of intangible assets and total assets. Companies with a large amount of goodwill compared to intangible assets and total assets, complied more with IAS 36 than other companies. In their study, Izzo et al. find that there is not a relation between the level of disclosure and the impairment rate, the goodwill on equity ratio and the market capitalization. The results we have obtained exhibit that the disclosure level depends on both the goodwill on intangible assets ratio and the goodwill on total assets ratio.

Our study has the following caveats. First, it focuses on a single country. Second, it is based on a single year. Regarding this limitation, it would be interesting to expand the period analysed in order to confirm our results. Notwithstanding these limitations, however, the research design provides an appropriate way to infer practical implications for both standard setters or regulatory bodies and industry. For Standard setters, the premise of the disclosures requirements about the goodwill impairment is that by gaining a better understanding of the links between the goodwill and its impairment, investors can better assess the risks associated with CGUs. Our study suggests that this objective can be achieved by a better regulation of the different rates used during the impairment test in order to reduce its subjectivity. Moreover, industry need more guidance in IAS 36 on how to perform the sensitivity test and the allocation of goodwill to CGUs. Companies should discuss the rationale behind the discount rates and long-term growth rates used to test for goodwill impairment. Our findings are in lines with the proposed amendments to the impairment test proposed by the European Financial Reporting Advisory Group. Those amendments aim to enhance the application and effectiveness of the impairment test and to reduce complexity.

With the constant evolution of standards, additional research will be needed to more fully understand the factors that link companies' attitudes and the disclosures requirements under IAS 36. Since IFRS are mandatory for all European listed companies, this study can be replicated on other European countries. Future work can also investigate the reasons of the non-compliance. In their answers to FSMA, some companies expressed their worry to disclose competitive information. This characteristic has to be analysed in order to improve the quality of the disclosure. Finally, it should be noted that not disclosing emphasizes the concerns of earnings management expressed in the literature (Carlin \& Finch, 2009).

\section{References}

André, P., Filip, A., \& Paugam, L. (2016). Examining the patterns of goodwill impairments in Europe and the US. Accounting in Europe, 13(3), 329-352. https://doi.org/10.1080/17449480.2016.1260748

André, P., Dionysiou, D., \& Tsalavoutas, I. (2018). Mandated disclosures under IAS 36 Impairment of Assets and IAS 38 Intangible Assets: value relevance and impact on analysts' forecasts. Applied Economics, 50(7), 707-725. https://doi.org/10.1080/00036846.2017.1340570

Baboukardos, D., \& Rimmel, G. (2014). Goodwill under IFRS: Relevance and disclosures in an unfavorable environment. Accounting Forum, 38(1). 1-17. https://doi.org/10.1016/j.accfor.2013.11.001

Bepari, M.K., Rahman, S.F., \& Mollik, A.T. (2014). Firms' compliance with the disclosure requirements of IFRS for goodwill impairment testing. Journal of Accounting and Organizational Change, 10(1), 116-149. https://doi.org/10.1108/JAOC-02-2011-0008

Bloom, M. (2009). Accounting for goodwill. Abacus, 45(3), 379-389. https://doi.org/10.1111/j.1467-6281.2009.00295.x

Botosan, C. A. (1997). Disclosure level and the cost of equity capital. The Accounting Review, 72(3), 323-349.

Carlin, T. M., Finch, N., \& Ford, G. (2007). Goodwill impairment-an assessment of disclosure quality and compliance levels by large listed Australian firms. MGSM Working Paper No. 2007-8. Available at SSRN 963078. https://doi.org/10.2139/ssrn.963078

Carlin, T. M., \& Finch, N., (2009). Discount rates in disarray: Evidence on flawed goodwill impairment testing. Australian Accounting Review, 19(4), 326-336. https://doi.org/10.1111/j.1835-2561.2009.00069.x

d'Arcy, A., \& Tarca, A. (2018). Reviewing IFRS goodwill accounting research: Implementation effects and cross-country differences. The International Journal of Accounting, 53(3), 203-226. https://doi.org/10.1016/j.intacc.2018.07.004

Devalle, A., \& Rizzato, F. (2012). The quality of mandatory disclosure: the impairment of goodwill. An 
empirical analysis of European listed companies. Procedia Economics and Finance, 2, 101-108. https://doi.org/10.1016/S2212-5671(12)00069-X

Devalle, A., Rizzato, F., \& Busso, D., (2016). Disclosure indexes and compliance with mandatory disclosure The case of intangible assets in the Italian market. Advances in Accounting incorporating. Advances in International Accounting, 15, 8-25. https://doi.org/10.1016/j.adiac.2016.04.003

Devine, C. T. (1985). Essays in Accounting Theory. Volumes IV. Studies in Accounting Research, 22, American Accounting Association.

ESMA. (2013). European enforcers review of impairment of goodwill and other intangible assets in the IFRS financial statements. Retrieved from http://www.esma.europa.eu

Fabre, K., \& Farjaudon, A. L. (2005). Ecart d'acquisition et normes IAS/IFRS : une étude empirique des pratiques des entreprises françaises. Comptabilité et Connaissances. pp CD-Rom. Retrieved from https://hal.archives-ouvertes.fr/file/index/docid/581193/filename/43.pdf

Gao, R., \& Sidhu, B. K. (2018). The Impact of Mandatory International Financial Reporting Standards Adoption on Investment Efficiency: Standards, Enforcement, and Reporting Incentives. Abacus, 54(3), 277-318. https://doi.org/10.1111/abac.12127

Gélard, G. (2013). Pourquoi le goodwill pose problème (s). Revue Française de Comptabilité, (466), 29.

Glaum, M., Schmidt, P., Street, D. L., \& Vogel, S. (2013). Compliance with IFRS 3- and IAS 36-required disclosures across 17 European countries: Company- and country-level determinants. Accounting \& Business Research, 43(3), 163-204. https://doi.org/10.1080/00014788.2012.711131

Hartwig, F., (2015). Swedish and Dutch listed companies' compliance with IAS 36 paragraph 134. International Journal of Disclosure and Governance, 12, 78-105. https://doi.org/10.1057/jdg.2013.33

Hodgdon, C., Tondkar, R. H., Harless, D. W., \& Adhikari, A. (2008). Compliance with IFRS disclosure requirements and individual analysts' forecast errors. Journal of International Accounting, Auditing and Taxation, 17(1), 1-13. https://doi.org/10.1016/j.intaccaudtax.2008.01.002

International Accounting Standard Board. (2004a). IAS 36-Impairment of assets. Retrieved from http://www.iasb.org

International Accounting Standard Board. (2004b). IFRS 3-Business Combinations. Retrieved from http://www.iasb.org

Izzo, M. F., Luciani, V., \& Sartori, E. (2013). Impairment of goodwill: Level of compliance and quality of disclosure during the crisis-An analysis of Italian listed companies. International Business Research, 6(11), 94.

Johnson, L. T., \& Petrone, K. R. (1998). Commentary: is goodwill an asset? Accounting Horizons, 12(3).

Leake, P. D. (1921). Commercial goodwill: its history, value, and treatment in accounts. Sir J. Pitman \& sons, ltd.

Libby, R., \& Brown, T. (2013). Financial Statement Disaggregation Decisions and Auditors' Tolerance for Misstatement. The Accounting Review, 88(2), 641-665. https://doi.org/10.2308/accr-50332

Libby, R., Rennekamp, K. M., \& Seybert, N. (2015). Regulation and the interdependent roles of managers, auditors, and directors in earnings management and accounting choice. Accounting, Organizations and Society, 47, 25-42. https://doi.org/10.1016/j.aos.2015.09.003

Lys, T. Z., Vincent, L., \& Yehuda, N. (2012). The nature and implications of acquisition goodwill. Available at SSRN 1802612. http://dx.doi.org/10.2139/ssrn.1802612

Marston, C. L., \& Shrives, P. J. (1991). The use of disclosure indices in accounting research: a review article. The British Accounting Review, 23(3), 195-210. https://doi.org/10.1016/0890-8389(91)90080-1

Mazzi, F., André, P., Dionysiou, D., \& Tsalavoutas, I. (2015). Goodwill related mandatory disclosure and the cost of equity capital. Available at SSRN 2464154.

Mazzi, F., André, P., Dionysiou, D., \& Tsalavoutas, I. (2017). Compliance with Goodwill-Related Mandatory Disclosure Requirements and the Cost of Equity Capital. Accounting and Business Research, 47(3), 268-312. https://doi.org/10.1080/00014788.2016.1254593

Nelson, R. H. (1953). The momentum theory of goodwill. The Accounting Review, 28(4), 491-499. 
Onali, E., Ginesti, G., \& Ballestra, L. V. (2017). Investor reaction to IFRS for financial instruments in Europe: The role of firm-specific factors. Finance Research Letters, 21, 72-77. https://doi.org/10.1016/j.frl.2017.01.002

Petersen, C., \& Plenborg, T. (2010). How do firms implement impairment tests of goodwill? Abacus, 46(4), 419-446. https://dx.doi.org/10.1111/j.1467-6281.2010.00326.x

Ratiu, R. V., \& Tudor, A. T. (2013). The theoretical foundation of goodwill - A chronological overview. Procedia-Social and Behavioral Sciences, 92, 784-788. https://doi.org/10.1016/j.sbspro.2013.08.755

Schatt, A., Doukakis, L., Bessieux-Ollier, C., \& Walliser, E. (2016). Do goodwill impairments by European firms provide useful information to investors? Accounting in Europe, 13(3), 307-327. https://doi.org/10.1080/17449480.2016.1254348

Street, D. L., Gray, S. J., \& Bryant, S. M. (1999). Acceptance and observance of international accounting standards: An empirical study of companies claiming to comply with IASs. The International Journal of Accounting, 34(1), 11-48. https://doi.org/10.1016/S0020-7063(99)80002-8

Appendix 1. Mandatory disclosure grid

\begin{tabular}{|c|c|}
\hline Item & Score* \\
\hline \multicolumn{2}{|l|}{ Requirements related to CGU } \\
\hline \multicolumn{2}{|l|}{$\begin{array}{l}\text { Has the company disclosed the carrying amount of goodwill allocated to the CGU? (IAS 36, } \\
\text { paragraph 134(a)) }\end{array}$} \\
\hline \multicolumn{2}{|l|}{$\begin{array}{l}\text { Has the company disclosed the basis on which the CGU's recoverable amount has been } \\
\text { determined (i.e. value in use or fair value less costs to sell)? (IAS 36, paragraph 134(c)) }\end{array}$} \\
\hline \\
\hline $\begin{array}{l}\text { Has the company disclosed each key assumption on which management has based its cash flow } \\
\text { projections for the period covered by the most recent budgets/forecasts? (IAS 36, paragraph } \\
\text { 134(c)(i)) }\end{array}$ & \\
\hline $\begin{array}{l}\text { Has the company disclosed the management's approach to determining the value(s) assigned to } \\
\text { each key assumption? (IAS 36, paragraph 134(c)(ii)) }\end{array}$ & \\
\hline $\begin{array}{l}\text { Has the company disclosed the period over which the cash flows have been projected? (IAS 36, } \\
\text { paragraph 134(c)(iii)) }\end{array}$ & \\
\hline $\begin{array}{l}\text { Has the company disclosed the growth rate used to extrapolate cash flow projections beyond the } \\
\text { period covered by the most recent budgets/forecasts?? (IAS 36, paragraph 134(c)(iv)) }\end{array}$ & \\
\hline $\begin{array}{l}\text { s the company disclosed the discount rate(s) applied to the cash flow projections? (I } t \\
\text { agraph } 134(\mathrm{c})(\mathrm{v}))\end{array}$ & \\
\hline
\end{tabular}

Requirements related to the fair value less costs to sell

Has the company disclose the method used to measure fair value less costs of disposal? (IAS 36, paragraph 134(e))

If fair value less costs to sell is not determined using an observable market price for the CGU

Has the company disclosed each key assumption on which management has based its cash flow projections for the period covered by the most recent budgets/forecasts? (IAS 36, paragraph 134(e)(i))

Has the company disclosed the management's approach to determining the value(s) assigned to each key assumption? (IAS 36, paragraph 134(e)(ii))

If fair value less costs to sell is determined using discounted cash flow projections

Has the company disclosed the period over which management has projected cash flows? (IAS 36, paragraph 134(e)(iii))

Has the company disclosed the growth rate used to extrapolate cash flow projections? (IAS 36, paragraph 134(e)(iv))

Has the company disclosed the discount rate(s) applied to the cash flow projections? (IAS 36, paragraph 134(e)(v))

\section{Requirements related to the sensitivity analysis}

Has the company run a sensitivity analysis and disclosed change made in keys assumptions and the amount by which the unit's (group of units') recoverable amount exceeds it carrying amount?

*If YES $=1$ point, No $=0$ point

\section{Copyrights}

Copyright for this article is retained by the author(s), with first publication rights granted to the journal.

This is an open-access article distributed under the terms and conditions of the Creative Commons Attribution license (http://creativecommons.org/licenses/by/4.0/). 